\title{
NEW GEOLOGICAL RECONNAISSANCE MAPPING IN THE AREA BETWEEN NORDRE STR $\emptyset$ MFJORD AND IKERTOQ FJORD
}

\author{
A. Escher
}

\section{Introduction}

In the years 1965 and 1966, geological reconnaissance mapping and interpretation of aerial photographs of the inland areas between Nordre Str $\phi \mathrm{m}$ fjord and Ikertoq fjord was carried out. This work was done as a part of the current 1:500 000 mapping project. It completed as far as possible the earlier coastal mapping by Noe-Nygaard and Ramberg (1961).

The Ikertoq complex

Field evidence shows that most of the thick amphibolite horizons which occur abundantly around Ikertoq fjord, are not derived from the Kangamiut dolerite dykes. In several places the thick concordant amphibolites are cut by sub-concordant boudinaged and sheared meta-dolerites which are similar to the transformed Kangâmiut dykes described by Ramberg (1949) in the inner part of S $\phi$ ndre Str $\phi$ mfjord. Moreover, in the inland area east of Ikertoq fjord, the concordant amphibolites contain in many places layers of graphite-bearing biotite schist. Amphibolites and schists are here folded and refolded by two major phases of deformation (ENE and NW axial trends).

The Isortoq complex

There exists a major tectonic discordance between the rocks of the Ikertoq complex and those of the Isortoq complex. This zone of faulting and shearing can clearly be followed to the east, up to the inland ice. It is regularly dipping to the NNW and represents probably a thrust zone which is more or less concordant with the foliation of the gneisses. Structural evidence suggests that there have been dextral wrench movements along the fault zone.

The garnet-bearing quartz-feldspar granulites, south of Nordre Isortoq fjord, show in many places sedimentary structures (current bedding, graded bedding) suggesting that they may have been originally arkosic sandstones. Locally the absence of feldspar indicates a more quartzitic composition.

The Isortoq complex can be divided structurally in three units: 
a north and a south unit, affected probably by the same two successive deformations which folded the Ikertoq complex, and a central unit which shows in addition the effects of a still earlier deformation.

This central unit lies roughly between Nordre Str $\phi$ mfjord and Nordre Isortoq fjord. Its structural pattern is characterised by the presence of large scale "eyed" folds. It may represent an area of older pre-Nagssugtoqidian basement, reworked by the Nagssugtoqidian folding.

Noe-Nygaard and Berthelsen (1953) have already mapped a large part of these central structures.

The south part of the Egedesminde complex

Geological mapping of the inner part of Nordre Strømfjord shows that there was only one major folding (axial trend ENE) which affected the rocks in this area. Between Ugssuit and the inland ice, two large synclines of supracrustals were observed. The rocks are mainly quartzites, metavolcanics and semipelitic schists.

No stratigraphical discordance could be found between these rocks and the underlying gneisses.

\section{References}

Noe-Nygaard, A. and Berthelsen, A (1953) On the structure of a high-metamorphic gneiss complex in West Greenland, with a general discussion on related problems. Medd. dansk geol. Foren., Bd.12, [for 1952] 250-265.

Noe-Nygaard, A. and Ramberg, H. (1961) Geological reconnaissance map of the country between latitudes $69^{\circ} \mathrm{N}$ and $63^{\circ} 45 \mathrm{~N}$, West Greenland. Medd. Grфnland, Bd.123, Nr.5.

Ramberg, A. (1949) On the petrogenesis of the gneiss complexes between Sukkertoppen and Christianshaab, West-Greenland. Medd. dansk geol. Foren., Bd.11, [for 1948] 312-327. 